\title{
CLASSROOM ACTION RESEARCH: USING COOPERATIVE LEARNING (TEAM PAIR SOLO) TO IMPROVE NURSING STUDENTS' SPEAKING SKILL
}

\author{
Wahyu Wibisono \\ wahyu_kuromon@yahoo.com \\ STIKESS Patria Husada Blitar
}

\begin{abstract}
Mastering many languages is a softskill that every nurse must acquire in order to make patients feel comfortable and decrease the anxiety.. English is one of many languages which is widely used in the world. So, it is important to a nurse to be able to communicate using English. This research was intended to apply cooperative learning TPS (Team Pair Solo) as the technique to enhance students' Englishspeaking skill when they took the "communicating class" in the fifth semester in Stikes Patria Husada Blitar. This research was a Classroom Action Research. The subject was 10 students of the fifth semester. The researcher used several instruments; such as observation checklist, field notes, test, and questionnaire. The findings showed that TPS were effective in improving the speaking skill of the student in class. This could be seen by the increase of students' mean scores in the test results 65.1 in preliminary study became 81.3 in the first cycle and this also meant that $100 \%$ students could pass the minimum passing grade of 78 which was setted by the researcher as the criteria of success of the research itself. The improvement could also be seen on the results of the field notes that showed positivity, raise of motivation, and good responses from the students. It showed that by using cooperative learning (Team Pair Solo), students' motivation and self-esteem increased since the TPS could accommodate students to be well prepared before they speak by discussing in team, pair with other student, and finally they have great self-esteem to stand by their self infront of the class. Other researchers were expected to elaborate this cooperative learning with other technique so that there would be alot of technique could be used as reference in teaching English.
\end{abstract}

Keywords: classroom action research, cooperative learning (Team Pair Solo), speaking skill

\section{INTRODUCTION}

Learning a language requires both receptive skills and productive skills. The teaching of English as foreign language includes those two categorized skills. Levine et al. (2000) stated that listening and reading are considered to be receptive skills, whereas speaking and writing are considered to be productive skills. The aim of the teaching of the receptive skills is to understand meaning conveyed in different text types (recount, narrative, procedure, descriptive, news item, spoof, report, analytical exposition, hortatory exposition, discussion and review texts), while the teaching of productive skills aims at teaching students to express meaning in these text types. Therefore, it can be concluded that speaking is considered as one of the most important skills that students need to acquire (Nashriyah, 2010).

Speaking is one of the productive activities in daily life and is the most important language skill because it is the main skill needed to carry out a conversation. Besides, speaking is an interactive process for constructing and receiving information. Specifically, the mastery of speaking is a priority for students in schools and universities. In the communicative model of speaking class, the students should be taught how to speak well by using the components of English speaking skills, such as communication, grammar, vocabulary, 
fluency and comprehension (Afrizal, 2005)

Mastering many languages is a softskill that every nurse must acquire in order to make patients feel comfortable and decrease the anxiety. English is one of many languages which is widely used in the world. So, it is important to a nurse to be able to communicate using English. Based on the researcher's experience in teaching the nursing students of STIKes Patria Husada Blitar, the EFL students frequently get difficulties in English. Speaking became the scariest activity in class sinceit requires high concentration, motivation, and courage to deal with. Based on the observation, the students were low motivated and were not interested to speak in "communicating class". They consider that speaking was a fearsome activity. Moreover, the teaching learning process was still insufficient in the classroom since the traditional grammar translation method was used as the method in teaching speaking. First step which was essential to be done was modified the teacher's technique since teacher played an important role in managing the class so that students would not get bored, ashamed to speak, feared with the class, and became more excited to speak English. Next, the condition of the teaching learning process in the class should be changed into more cooperative atmosphere between teacher and students and among students and avoided competitive atmosphere in order to create a conducive teaching learning process during the class. In dealing with those problems, the researcher proposed to use cooperative learning named TPS (Team Pair Solo) as the technique to improve students' speaking skill in "communicating class" on fifth semester.

Cooperative learning is considered suitable with students need because it is different from the traditional grammar translation method. In cooperative learning, students need to work together rather than having competition to each other during the teaching learning process. It is usually done by giving structured project in a small group for students to work together cooperatively. Leighton (2002) stated that cooperative learning is an instructional task design that engages students actively in achieving lesson objectives through their own effort and the efforts of the member of their small learning team. It means that in cooperative learning, students' learning success is not only determined by their own effort, but also the member of the group.

TPS which is stands for Team Pair Solo, according to Kagan (2001) Team Pair Solo is a technique which can develop students' virtue learning. There are several virtues acquired through Team Pair Solo such as cooperation, helpfulness, leadership, self-motivation, and pride in one's work. In this technique students learn and work together in group before solving similar problems individually. During the group working process, students can help, coach, and share information. In that process, students will be motivated in learning because they will be held individually accountable in the third step of the technique (Kagan, 2001). According to Johnson (2006) Team Pair Solo technique is designed to motivate students to tackle and succeed at problems which initially are beyond their ability. It is based on a simple notion of mediated learning. Students can do more things with help (mediation) than they can do alone. By allowing them to work on problems they couldn't do by theirself, first as a team and then with the partner, they progress to a point they can do alone that which at first they could do only with help (Johnson, 2006).

Based on the researcher's experience in dealing with the students in STIKes Patria Husada Blitar, the nursing 
students frequently get difficulties in English especially when they were asked to speak infront of the class. Observation on the preliminary study revealed that students' difficulty in speaking was caused by students low motivation and interest to join the English class since it was only an additional subject on the nursing college. They felt that learning English especially speaking was hard to do and fearsome. Moreover, the teaching learning process was still insufficient in the classroom since the method used traditional grammar transactional method which was done in a teacher centered way. The first things which need to be solved was the teacher's technique in "communicating class" especially in teaching the speaking skill because teacher must be able to control, manage, and support the students so that students would not get bored and also felt excited on joining the "communicating class". After that, the the teaching learning atmosphere in the class should be changed into more cooperative between teacherstudents and students-students and avoid competitive atmosphere in order to create a conducive teaching learning process in reading class. In dealing with those problems, the researcher was interested in using TPS (Team Pair Solo) as the technique to enhance students' speaking skill.

\section{METHOD}

This research was a classroom action research which was intended to solve a particular problem faced by the teacher in the teaching and learning process, especially in teaching speaking. A classroom action research design was chosen since it was considered to be suitable with the problems faced by the students in mastering the lessons. The students had difficulties to speak English. Moreover, the researcher tried to solve the problem by proposing TPS as the technique in teaching speaking. It was in line with the basic point of the classroom action research that was to propose a strategy, technique, or technique in the teaching and learning process to overcome the students' problem in mastering a particular subject.

\section{DISCUSSION}

In conducting the research, the researcher collaboratively assisted by a collaborator who was involved in the whole process of the research activity such as arranging the lesson plan, instructional material, teaching learning activities, the action, and evaluation. The subject of this research was 10 students of nursing department in fifth semester. The research design used collaborative classroom action research which was intended to solve a particular problem encountered by a teacher in the teaching and learning process, especially in the teaching reading. The researcher uses the steps proposed by Kemmis and Mc Taggart (1998). The steps were preliminary study, analyzing and identifying the problem, then planning the action, observing, analyzing, and reflecting. In conducting the research, the researcher worked collaboratively with one collaborator who was involved from the beginning up to the end of the process of the research activity in arranging the lesson plan, instructional material, and teaching learning activities, the action, and evaluation. Before starting the research activity, the researcher and the collaborator discussed all of the things related to the process in order to meet the same perception about the strategy being implemented, the procedure of the teaching and learning process being carried out, how to collect the data using the instruments, and how to score the students' test using the scoring rubric. During the process of implementing the strategy, the collaborator observed the 
students' activities by using observation checklist and field notes. After implementing the strategy, the teacher and the collaborator conducted reflection or discussion. In this session, the researcher and the collaborator analyzed the data from observation checklist, field notes, and the result of the test, in order to find out whether the criteria of success in use are achieved or not. Finally, the researcher and the collaborator drew the conclusion.

The result of the research revealed how TPS (Team Pair Solo) could improve students' speaking skill and also could increase their motivation to join "communicating class". In order to find out students' problem in speaking English, preliminary research data were provided before presenting the research findings in Cycle 1. In table 4.1, none of the students were in the level of excellent, many of them were in the category of fair in their score of speaking test. Eventhough most of them already passed the minimum standard of passing grade, but this was still a problem since their score were only a bit higher than the minimum standard. In relation to the student's final scores in preliminary research, based on table 4.1 , it could be seen that 10 students got BC. The researcher found out that all students had already passed the minimum passing grade of school subject BC (64). But it was still a problem since the researcher setted the minimum passing grade itself as $\mathrm{AB}$ (78) as the minimum standard of passing "communicating class" subject. The numbers of the students who passed and did not pass the minimum passing grade that the researcher setted could be seen in Table 4.2.

Table 4.1 Students' Score of each Indicators in Preliminary Research

\begin{tabular}{llllc}
\hline Level & Fluency & $\begin{array}{c}\text { Pronun } \\
\text { ciation }\end{array}$ & $\begin{array}{l}\text { Voca } \\
\text { bular } \\
\text { y }\end{array}$ & Grammar \\
\hline Excellent & 0 & 0 & 0 & 0 \\
Very & 0 & 0 & 1 & 1 \\
\hline
\end{tabular}

\begin{tabular}{lllll}
\hline good & 1 & 1 & 0 & 1 \\
Good & 9 & 9 & 9 & 1 \\
Fair & 0 & 0 & 0 & 7 \\
Poor & & & & \\
\hline Total & 10 & 10 & 10 & 10
\end{tabular}

Table 4.2 Students' Final Score of Speaking Test in Correlation with the Minimum Passing Grade in Preliminary Research

\begin{tabular}{lcl}
\hline Score & Number of Students & Category \\
\hline$>78$ & 0 & Passed \\
$<78$ & 10 & did not pass \\
\hline Total & 10 &
\end{tabular}

All of the students score for each aspect in testing speaking skill could be seen in Table 4.3. In this table, the students' made some improvement in their speakingcompared to the scores in preliminary research. There was no student in the level of poor and fair. Most of the students' were in the level of good and very good.

Table 4.3 Students' Reading Score of each Indicators in Cycle 1

\begin{tabular}{lcccc}
\hline Level & Fluency & $\begin{array}{c}\text { Pronun } \\
\text { ciation }\end{array}$ & $\begin{array}{c}\text { Vocab } \\
\text { ulary }\end{array}$ & Grammar \\
\hline Excellent & 3 & 2 & & \\
Very & 7 & 4 & & \\
good & 0 & 4 & & \\
Good & 0 & 0 & & \\
Fair & 0 & 0 & & \\
Poor & & & & \\
\hline Total & 10 & 10 & 0 & 0
\end{tabular}

In relation to the students' final scores in Cycle 1, based on table 4.3, 3 students got score $\mathrm{A}, 3$ students got $\mathrm{AB}$, and 4 students got $\mathrm{B}$. Based on the result of the students' speaking test, there was a great improvement of the students' average score from in preliminary research to the students' score on Cycle 1. The average score on the preliminary research was 65.1 and the average score of the students' speaking test on cycle 1 was 81.3. It meant that there was 16.2 point of average score improvement. In preliminary research, none of the students achieved the score above the criteria of 
success that the researcher was setted. Meanwhile, in Cycle 1, all of the students had already passed the minimum score of passing grade or criteria of success that was 78 or B. For detailed information about the improvement of the students' score in Cycle 1 compared to the score in the preliminary research can be seen in Table 4.4

Table 4.4 Students' Improvement in Speaking Test in Cycle 1.

\begin{tabular}{|c|c|c|c|c|c|}
\hline 0 & Aspects & $\begin{array}{l}\text { Prelim } \\
\text { inary } \\
\text { Resear } \\
\text { ch }\end{array}$ & $\begin{array}{l}\text { Cycl } \\
\text { e } 1\end{array}$ & $\begin{array}{l}\text { Percenta } \\
\text { Prelim } \\
\text { inary } \\
\text { Resear } \\
\text { ch }\end{array}$ & Cycle 1 \\
\hline & $\begin{array}{l}\text { Average } \\
\text { Score }\end{array}$ & 65.1 & 81,3 & - & - \\
\hline & Min Score & 64 & 75 & - & - \\
\hline & $\begin{array}{l}\text { Max } \\
\text { Score }\end{array}$ & 66 & 88 & - & - \\
\hline & $\begin{array}{l}\text { Criteria of } \\
\text { Success }\end{array}$ & 78 & 78 & - & - \\
\hline & $\begin{array}{l}\text { Achieving } \\
\text { Criteria of } \\
\text { Success }\end{array}$ & 0 & 10 & $\%$ & $100 \%$ \\
\hline & $\begin{array}{l}\text { Not } \\
\text { Achieving } \\
\text { Criteria of } \\
\text { Success }\end{array}$ & 10 & 0 & $100 \%$ & $0 \%$ \\
\hline
\end{tabular}

Based on the students' scores on table 4.4, it could be concluded that the implementation of TPS (Team Pair Solo) in Cycle 1 met the criteria of success or minimum passing grade that was setted by the researcher. The average score was 81.3. None of the students got score under 64. The lowest score in cycle 1 were BC which were acquired by 3 students, 5 students got score $\mathrm{B}$, and 2 students got score AB. The student's lowest score was 75 and the highest students' score was 88 . The data above showed that students' achievement in their speaking test had achieved the criteria of success. There was also an improvement in terms of the aspect of speaking test.

Table 4.5 Students' Final Score of Speaking Test in Correlation with the Minimum Passing Grade in Cycle 1

\begin{tabular}{ccl}
\hline$>64$ & 10 & Passed \\
$<64$ & 0 & did not pass \\
\hline Total & 10 &
\end{tabular}

Based on the score of the students' final product in Cycle 1, it could be concluded that the implementation of the strategy on cycle 1 had met the criteria of success. The average score of the students in Cycle 1 was 81,3. In addition, all of the students or $100 \%$ of the students had reached the criteria of success.

\section{CONCLUSIONS}

Cooperative learning (Team Pair Solo) were succeed to be used in achieving the objective of teaching the speaking skill of the students. The objective was to master certain speaking skill indicators such as fluency, pronunciation, vocabulary, and grammar. In this case, cooperative learning (Team Pair Solo) was very useful because it motivated the students to join the class, built cooperative atmosphere in class, and also increase students' self esteem to speak with others in front of the class. Cooperative learning (Team Pair Solo) was very useful for both students and teacher. Students did not hesitate and fearful to express their ideas and had more time to think and discussing before they speak or gave comments in front of the class. Direct feedback for grammatical error and mispronunciation was also given by the teacher and other students could also made students got used to speak in a proper and correct pronunciation. Students' enthusiasm in class was also increased since they got direct feedback from the teacher and other students. Their confidence and motivation to speak were also increase day by day since they were accustomed to speak and discus with other students. Most of the students were able to keep this reduced level of mistakes throughout the five-week period. Bringing cooperative learning (Team Pair Solo) intcatteorglass is a great icebreaker, and 
serves as a useful tool to improve students' speaking skill. Using cooperative learning (Team Pair Solo) could also generate interest and help create an atmosphere conducive to learning.

\section{REFERENCES}

Afrizal,M. 2015. A Classroom Action Research: Improving Speaking Skills Through Information Gap Activity. EEJ (English Education Journal).

Brown, H. D. 2004. Language Assessment: Principles and Classroom Practices. New York: Pearson Education

Celce-Murcia, M. \& Hilles, S. 1998. Techniques and Resources in Teaching Grammar. Hongkong: Oxford University Press

Educause Learning Initiative 2006. 7 things you should know about Cooperative learning (Team Pair Solo). Retrieved January 6, 2012. http://net.educause.edu/ir/library/p df/ELI7017.pdf

Jones, Anthony S.D.,\& The Black River Group. 1994. The Expert Educator. Fond du Lac WI: Three Blue Herons Pub
Johnson, D. W., Johnson, R. T. \& Smith, K. A. (2006). Active Learning: Cooperation in the College Classroom. Edina, MN: Interaction Book Company.

Kagan, S. 2001. Kagan Online Magazine: Kagan Structures for Emotional Intelligence. Retrieved January 6, 2012.

http://www. KaganOnline.com

Kemmis, S. \& Mc. Taggart, R. 2005. The Action Research Planner $13^{\text {th }}$ ed. Victoria: Deakin University Press

Leighton, M. S. (2002). Classroom teaching skills: cooperative learning.

Nashriyah.(2010). A Study of Indonesian Students' Reading Strategies. IIEF, Jakarta: Embassy of United States.

Rivers, W. 1981. Teaching Foreign Language Skills. Chicago: The University of Chicago Press

Tim Penyusun Kurikulum STIKes Patria Husada. 2011. Panduan Pendidikan Ners dan Bidan STIKes Patria Husada Blitar. Blitar: STIKes Patria Husada 